Review

\title{
Hypothalamic Obesity in Craniopharyngioma Patients: Disturbed Energy Homeostasis Related to Extent of Hypothalamic Damage and Its Implication for Obesity Intervention
}

\section{Christian L. Roth}

Seattle Children's Hospital Research Institute, University of Washington, Department of Pediatrics, Center for Integrative Brain Research, 1900 Ninth Ave, P.O. Box 5371 M/S-C9S, Seattle, WA 98101, USA; E-Mail: christian.roth@seattlechildrens.org; Tel.: +206-987-5428; Fax: +206-987-7661

Academic Editors: Günter Stalla and Anna Kopczak

Received: 30 June 2015 / Accepted: 31 August 2015 / Published: 9 September 2015

\begin{abstract}
Hypothalamic obesity (HO) occurs in patients with tumors and lesions in the medial hypothalamic region. Hypothalamic dysfunction can lead to hyperinsulinemia and leptin resistance. This review is focused on HO caused by craniopharyngiomas (CP), which are the most common childhood brain tumors of nonglial origin. Despite excellent overall survival rates, $\mathrm{CP}$ patients have substantially reduced quality of life because of significant long-term sequelae, notably severe obesity in about $50 \%$ of patients, leading to a high rate of cardiovascular mortality. Recent studies reported that both hyperphagia and decreased energy expenditure can contribute to severe obesity in HO patients. Recognized risk factors for severe obesity include large hypothalamic tumors or lesions affecting several medial and posterior hypothalamic nuclei that impact satiety signaling pathways. Structural damage in these nuclei often lead to hyperphagia, rapid weight gain, central insulin and leptin resistance, decreased sympathetic activity, low energy expenditure, and increased energy storage in adipose tissue. To date, most efforts to treat $\mathrm{HO}$ have shown disappointing long-term success rates. However, treatments based on the distinct pathophysiology of disturbed energy homeostasis related to CP may offer options for successful interventions in the future.
\end{abstract}

Keywords: hypothalamic obesity; craniopharyngioma; risk factors; neuroimaging; rodent models; inflammation; pharmacological interventions 


\section{Introduction}

Childhood obesity of any cause is a major risk factor for adult cardiovascular disease (CVD), the leading cause of death in the US [1]. In 2009-2010, 16.9\% of US children and adolescents were obese ( $>95$ th BMI percentile) and rates of pre-diabetes and diabetes are still rising [2,3]. Approximately $84 \%$ of youth with severe obesity already have at least one CVD risk factor, and most adolescents with type 2 diabetes mellitus (T2DM) are obese [4]. In recent years, it has become clear that obesity can be associated with disturbed hypothalamic control of adiposity signaling peptides, such as leptin. The most striking examples of treatment resistant childhood obesity are observed in patients with dysfunctional hypothalamic signaling, such as in Prader-Willi syndrome, hypothalamic obesity (HO) due to craniopharyngioma (CP), or in subjects with deficient melanocortin signaling, leading to hyperphagia and excessive weight gain [5]. This review focuses on HO secondary to hypothalamic damage in patients with $\mathrm{CP}$.

\section{Clinical Manifestations and Risk Factors}

\subsection{Hypothalamic Obesity Syndrome}

Excessive weight gain frequently occurs in patients with hypothalamic tumors and lesions, a disorder designated as hypothalamic obesity (HO). HO syndrome is characterized by fatigue, decreased physical activity, hyperphagia, decreased satiety, and severe obesity. All features are frequently seen in patients suffering from $\mathrm{HO}$ due to craniopharyngioma (CP) [6,7] as well as other causes of hypothalamic dysfunction and damage, such as other suprasellar tumors, inflammation, and genetic syndromes [6,8-11].

\subsection{Hypothalamic Obesity in Patients with Craniopharyngioma}

CP tumors are histologically benign (WHO Grade I), and are the most common suprasellar tumors of nonglial origin in children [12]. There are two peak age ranges: adolescence (10-19 year) and older adults $(65-74$ year), with $30 \%-50 \%$ of all CP cases occurring in childhood $[13,14]$. US data show $5.4 \%$ of all childhood (ages 0-19 year) brain and central nervous system tumors from 2006 to 2010 were CP [15]. Quality of survival is substantially reduced due to comorbid metabolic consequences [16-19]. Despite optimal endocrine management of hypopituitarism, severe obesity, a major risk factor for CPrelated morbidity and mortality [20,21], occurs in about 50\% of CP survivors [22-25]. Recent data show that hypothalamic involvement has major negative impact on long-term prognosis. Sellar masses with hypothalamic involvement were associated with lower overall survival and higher BMI at diagnosis and follow-up when compared with sellar masses without hypothalamic involvement [26]. The strongest weight gain occurs during the first 12 months following surgery [25]. While many patients report hyperphagia, recent studies have also reported an overall decrease in energy intake in patients with HO compared with controls [27,28]. Reduction in energy intake is offset by greater relative decrease in basal metabolic rate and physical activity related energy expenditure in HO patients, which 
might explain in part why weight loss attempts through caloric restriction and exercise has been largely unsuccessful [29].

CP patients are reported to be less physically active than controls with comparable body mass indices (BMIs) [28]. Hyperinsulinemia, leptin resistance and low leptin binding activity have been demonstrated in CP patients [29-34]. The degree of hyperleptinemia and hyperinsulinemia are inappropriate for the degree of obesity, and the metabolic rate and catecholamine levels are lower in CP patients, indicating a reduced sympathetic tone $[6,27,28,30,35-40]$. In recent studies, obese CP subjects had significantly reduced serum alpha-melanocyte-stimulating hormone $(\alpha-\mathrm{MSH})$ levels $[35,41]$, higher baseline and post-meal insulin, and weaker post-meal gut hormone changes [27,32,37,39,40,42], indicating altered secretion of satiety-regulating hormones in CP. Reduced serum $\alpha$-MSH levels indicate melanocortin deficiency, which might explain lower energy expenditure in peripheral tissues via reduced fat and muscle fatty acid oxidation $[35,41,43]$. All these findings underscore the concept of disturbed satiety signaling in CP patients and that leptin resistance and a deficiency of downstream mediators of leptin signaling are key features in $\mathrm{HO}$ pathogenesis.

\subsection{Cardiometabolic Risk Factors}

$\mathrm{HO}$, caused by hypothalamic damage due to $\mathrm{CP}$ and its treatment, is one of the most refractory examples of childhood obesity leading to severe atherosclerotic CVD, T2DM and metabolic syndrome [44-46]. Patients with CP typically become obese and display more features of the metabolic syndrome compared to matched controls [34,44]. Overall, a 3-19-fold higher cardiovascular mortality has been reported [20,47], and a recent nationwide population-based study in Sweden demonstrated increased rates for cerebral infarction (seven-fold), death due to cerebrovascular diseases (five-fold), and type 2 diabetes mellitus (six-fold) in CP patients in comparison to the general population [21]. Thus, early and effective management of obesity is vital for these patients [48], which are more resistant to treatment than those with uncomplicated obesity [29,49-56].

\subsection{Risk Factors for Excessive Weight Gain}

Recognized risk factors for severe obesity include large hypothalamic tumors or lesions affecting several medial and posterior hypothalamic nuclei that impact satiety signaling pathways $[25,51,57,58]$. Structural damage in these nuclei often leads to hyperphagia, rapid weight gain, central insulin and leptin resistance, decreased sympathetic activity, low energy expenditure, and increased energy storage in adipose tissue [6,52]. Recently, Roth et al. developed a semi-quantitative assessment of hypothalamic damage on brain magnetic resonance imaging (MRI) to predict the risk for $\mathrm{HO}$ development in CP [25,59]. Beside neuroimaging criteria (see below), development of diabetes insipidus had been identified as an endocrine marker for increased HO risk [25]. However, no other hormonal abnormalities were identified that could serve as endocrine risk factors for $\mathrm{HO}$ development in patients who are adequately treated for endocrine disorders. In the same study, when comparing patients who developed $\mathrm{HO} v s$. no $\mathrm{HO}$, no differences were found in the rate of patients that received cranial irradiation in addition to brain surgery. Furthermore, in contrast to a previous study from Muller et al., which demonstrated a correlation between perioperative dexamethasone doses and weight gain during the first year following craniopharyngioma surgery [24], there was no evidence that 
post-operative weight gain and perioperative dexamethasone dose were related. However, patients with HO more commonly had histories of complete tumor resections, which is in agreement with other studies showing that less invasive and hypothalamus-sparing surgical approaches decrease the risk for HO development $[57,58,60,61]$.

\subsection{Key Brain Areas Involved in Disrupted Energy Homeostasis}

The hypothalamus is linked through direct synaptic connections to limbic systems that mediate motivation to eat and process reward [62,63]. Key regions thought to be the principal homeostatic brain areas responsible for regulating body weight are dispersed throughout the hypothalamus with important centers located in anterior (paraventricular nucleus, PVN), middle (arcuate nucleus, ARC, and ventromedial nucleus, $\mathrm{VMN}$ ) and posterior (dorsomedial nucleus, DMN, and dorsal hypothalamic area, DHA) regions. The ARC contains two well-studied neuronal populations [64], one expressing proopiomelanocortin, a precursor of $\alpha$-melanocyte stimulating hormone that inhibits food intake and stimulates energy expenditure; the other co-expressing agouti-related peptide and neuropeptide-Y, which both stimulate food intake and reduce energy expenditure. ARC neurons project to several brain areas of energy regulation, including the PVN, lateral hypothalamus, and dorsal hypothalamic nuclei [65]. The ARC expresses leptin receptors similar to the VMN and PVN [66]. The DMN contains gamma-aminobutyric acid and neuropeptide-Y expressing neurons as well as $\alpha$-melanocyte stimulating hormone terminals projecting from the ARC. DMN projections contribute to the stimulation of thyrotropin-releasing hormone neurons in the PVN [67]. DMN, DHA, and VMN are key nuclei for locomotion and thermoregulation, mediating leptin-induced sympathetic activation of brown adipose tissue and energy expenditure [68].

Disruption of feeding circuits by damage to medial hypothalamic nuclei due to tumor, surgery or irradiation, has the potential to increase hunger by unopposed activation of orexigens from the lateral hypothalamus, or by blocking response to adiposity signals such as leptin as well as proopiomelanocortin in the arcuate nucleus from the medial hypothalamus. In either case, the result can involve unopposed activation of the lateral hypothalamic area, and thereby orexigenic peptides (melanin-concentrating hormone $(\mathrm{MCH})$, hypocretin/orexin), or inhibition of anorexigenic peptides in the PVN (corticotropin-releasing factor, thyrotropin-releasing hormone, and oxytocin (OXT)), finally resulting in increased food intake and decreased energy expenditure. OXT is produced primarily in the PVN and supraoptic nucleus [69]. Leptin activates PVN OXT neurons through a melanocortin-4 receptor (MC4R) dependent mechanism, whereas leptin resistance is associated with downstream impairments in OXT release [70-72]. PVN OXT deficiency is seen in Prader-Willi syndrome and obese humans with mutations of the single-minded 1 gene [73,74]. CPs, by virtue of their hypothalamic location, have the potential to disrupt energy homeostasis at many levels, resulting in a complex clinical picture of $\mathrm{HO}$ syndrome characterized by severe obesity associated with leptin-resistance, fatigue, hyperphagia, impaired satiety, decreased sympathetic tone, and low energy expenditure [27,28,36,52,75-78]. 


\subsection{Functional Neuroimaging in Patients with CP}

Functional magnetic resonance imaging (fMRI) is a powerful tool for observing the human brain's in vivo responses to stimuli. One recent study tested satiety responses in a small group of four adolescent CP patients versus four BMI matched adolescent controls [79]. Following a test meal, controls showed suppression of activation by images of high-calorie, energy dense food while CP patients showed trends towards higher activation in regions of interest including the insula, nucleus accumbens, and medial orbitofrontal cortex. These results indicate a dysregulated connection between the hypothalamus and corticolimbic circuits involved in food reward and that perception of food cues may be altered in patients with HO, especially after eating, i.e., in the satiated state [79]. Another recent study tested $10 \mathrm{CP}$ patients with known hypothalamic involvement and 15 age- and intelligence-matched control subjects (median age: 17.8 and $17.3 \mathrm{y}$ ) by fMRI using an emotional face recognition task [80]. CP patients exhibited an abnormal pattern of task-induced activation and deactivation in the anterior and posterior rostral medial prefrontal cortex indicating that hypothalamic damage impacts neural correlates in other brain areas that are important for memory retrieval such as the medial prefrontal cortex. Therefore, the fMRI approach is encouraging for conducting mechanistic studies of the brain in future investigating how distinct brain lesions affect (i) responses to food cues and satiety in brain areas that are involved in motivation to eat, food reward and control of appetite as well as (ii) behavior and memory functions.

\subsection{Structural Neuroimaging in Patients with CP}

In several studies using structural neuroimaging, large structural defects affecting several medial hypothalamic nuclei were associated with the highest risk of obesity and often cause treatment-resistant uncontrolled appetite and rapid weight gain [6,37,38,57,58,81-84]. Rapid post-operative weight gain was identified as a predictor for severe long-term obesity [24,25,38]. Although there is strong evidence that hypothalamus-sparing surgery, potentially in combination with radiotherapy, decreases the occurrence of severe obesity without increasing the local recurrence rate [57,58], development of severe obesity following CP is still a major problem requiring identification of risk factors for obesity development which would allow early interventions.

In the most recent study, a novel hypothalamic lesion scoring (HLS) system was used to assess hypothalamic damage and predict the risk for development of hypothalamic obesity, which can be used pre- and post-surgery [25]. In this study, damage was assessed in relation to distinct areas that contain key neurons of energy homeostasis in contrast to previous studies that included measurements of the two- or three-dimensional assessments of hypothalamic damage and compression $[38,85,86]$. Furthermore, it needs to be considered that the whole human hypothalamus has a volume of about $4 \mathrm{~mL}$ [51], which is thereby much smaller than many of the CP tumors before surgery (often greater than $20 \mathrm{~mL}$ ). This scoring system qualitatively evaluates hypothalamic lesions using anatomical landmarks in sagittal and coronal MRI planes and does not require measurements or direct imaging of hypothalamic nuclei [25]. In addition, the HLS system differentiates between unilateral or bilateral damage of brain structures, as intact contralateral pathways could potentially compensate for deficient neurons and neuronal projections. Lesion scores are assessed in four standard images (Figure 1): 
(a) midsagittal (Figure 1A); (b) coronal section through the anterior commissure (Figure 1B); (c) coronal section midway between the anterior commissure and mammillary bodies (Figure 1C); and (d) coronal section through the mammillary bodies (Figure 1D). This procedure allows assessing seven criteria: (1) floor of the third ventricle which contains the arcuate nucleus; pituitary and pituitary stalk (Section a); (2) anterior hypothalamus including paraventricular nucleus which secretes antidiuretic hormone, corticotropin-releasing hormone, thyrotropin-releasing hormone, and oxytocin, as well as the suprachiasmatic nucleus, which is an important regulator for circadian rhythms (Section b); (3) medial hypothalamus containing the ventromedial nucleus, a key regulator for glucose metabolism, sympathetic tone, and satiety (Section c); (4) mammillary bodies (Section d); and (5) posterior hypothalamus containing the dorsomedial nucleus and posterior hypothalamic area which are important areas for thermoregulatory action, locomotion, heart rate and blood pressure regulation (Section d) [68]. In addition; (6) third and (7) lateral ventriculomegaly were assessed [25]. Compared to pre-surgical scoring, post-surgery lesion scoring correlated better with obesity outcomes [25]. Subjects with HO more frequently showed lesions affecting the anterior (paraventricular nucleus) and medial (includes arcuate and ventromedial nucleus) hypothalamus. However, the most robust weight gain was seen in subjects with lesions extending into the posterior hypothalamus containing the dorsomedial nucleus and dorsal hypothalamic area [25].

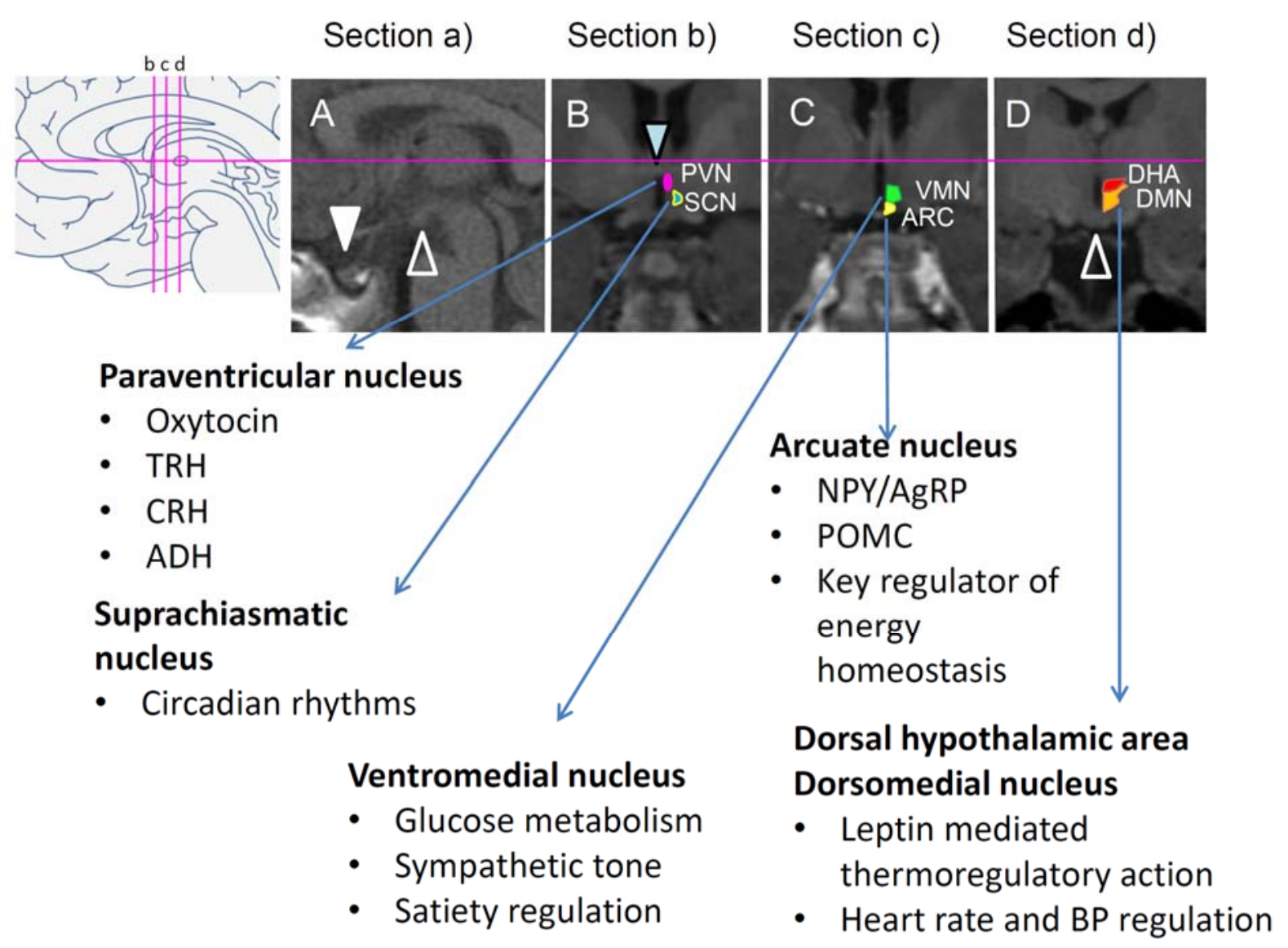

Figure 1. Standardized brain sections for assessment of brain lesions and hypothalamic nuclei that are critical for body weight regulation ((a) midline sagittal and (b-d) three coronal sections). Triangles point to landmarks of orientation: sella (white), anterior commissure (blue), and mammillary bodies (white open). 


\section{Studying Hypothalamic Obesity in Rats}

\subsection{Hypothalamic Lesion-Induced Obesity}

As in humans, studies in rodents demonstrate that lesions affecting the PVN, VMN and the floor of the third ventricle, and thereby the ARC, bear the highest risk for impaired satiety and excessive weight gain $[27,37,81,83,87,88]$. However, conflicting results have been published as PVN lesions lead to marked stimulation of food intake but variable frequency of obesity [89,90]. VMH-lesioned rats showed lower activity levels and disturbed circadian rhythms, whereas rats with PVH lesions did not [89]. Rodents treated at neonatal age with monosodium L-glutamate (MSG), which destroys $80 \%-90 \%$ of the ARC neurons [91,92], develop neuroendocrine and metabolic abnormalities, resulting in a phenotype of adiposity characterized by GH deficiency [93], hyperinsulinemia [94], and hyperleptinemia due to leptin resistance [95]. Vagotomy decreased high insulin secretion induced in MSG-obese rats [96]. Although still widely used in lesion-induced obesity models [97-102], MSG-induced damage is not limited to distinct hypothalamic nuclei as it also penetrates the brain on other sites of circumventricular organs, e.g., subfornical organ and area prostrema, as well as eyes and pituitary [91,92,103-106]. In addition, MSG-induced obesity is not associated with hyperphagia [88]. Recently Roth et al. developed a novel rat model of combined medial hypothalamic lesions (CMHL) to study the pathogenesis of $\mathrm{HO}$ and test potential drugs for obesity treatment and prevention $[6,41]$. The characteristic phenotype of human HO could only be replicated when the ARC was included in the brain lesions $[41,88]$. The CMHL model has large lesions affecting several medial hypothalamic regions including the $\mathrm{ARC}, \mathrm{VMN}$, and also the $\mathrm{DMN}$, leading to a more severe phenotype of $\mathrm{HO}$ and hyperphagia as well as melanocortin deficiency compared to smaller lesions and lesions of single nuclei $[6,35,37,38,41,88]$. As shown by different authors, the risk for gaining excess weight is particularly high during the immediate period following hypothalamic surgery [23-25]. During this critical time of rapid weight gain, brain inflammatory processes may be activated [107].

\subsection{Inflammation as Potential Contributor for Disturbed Hypothalamic Signaling}

Brain inflammatory responses are a hallmark of CP [107-109]. Increased interleukin (IL)-6 expression is observed in CP tissue and concentrations in cystic fluid reach levels 50,000-fold more than in cerebrospinal fluid. Increased IL-1 $\alpha$ and tumor necrosis factor (TNF)- $\alpha$ are also observed in CP cyst fluid [110]. What remains unknown, however, is the role of inflammation in tumor- or surgery-related excess weight gain and food intake. To what extent do hypothalamic inflammatory or CP-elicited inflammatory processes impact energy homeostasis? There is emerging evidence that in rodents, high-fat diets cause metabolic inflammation leading to neuroinflammation, reactive astrocytosis and astrogliosis, increased cytokine expression, neural dysregulation of the hypothalamus, neurodegeneration, and defective adult neurogenesis [10,111-113]. In the hypothalamus, this leads to insulin and leptin resistance, specifically inhibitor of $\kappa B$-kinase $\beta$ (IKKB/NF- $\kappa B$ ) activation and induction of suppressor of cytokine signaling (SOCS-3) [111,114-116]. Inflammation induced upregulation of SOCS-3, a marker of leptin and insulin resistance [117], can result in impaired ability of satiety signals, such as cholecystokinin-8, to activate neurons in the hindbrain and reduce food intake [118]. In rodent models, food intake can be inhibited by central suppression of 
IKKB [119-121]. These changes not only affect hypothalamic signaling, but also the regulation of energy homeostasis by downstream neurons [114,122-124], and may include reward pathways $[125,126]$.

Cellular components of neuroinflammation and repair after brain surgery include microglia and astrocytes with a maximum activation 5-7 days after insult [107]. Molecular components include pro-inflammatory interleukins, IL-1 $\beta$, IL-6, IL-8, and TNF- $\alpha$, which are produced by activated macrophages, T-cells, astrocytes, microglia and neurons [127], leading to neuronal dysfunction (see schematic overview in Figure 2). A deficient blood brain barrier is also observed in brain inflammation [128-130]. This can expose the brain to circulating endotoxins, such as lipopolyaccharides, which are ligands for toll-like receptor-4 (TLR4) [131]. TLR4s can also be stimulated by saturated fatty acids of a high-fat diet [113] and by binding endogenous danger molecules (heat shock proteins, hyaluronan, nucleic acids, and high mobility group box 1) in response to brain damage (Figure 2) [132]. TNF- $\alpha$ can induce endoplasmic reticulum (ER) stress [131]. The anti-inflammatory drug dexamethasone is frequently used perioperatively as a treatment for the prevention of cerebral edema and adrenal insufficiency, but bears the risk of excess weight gain. However, considering the mechanisms linked to inflammation listed above, abnormal weight gain can potentially be prevented by beneficial inhibition of inflammatory responses following hypothalamic surgery. The effects of other anti-inflammatory drugs could be tested in future studies.

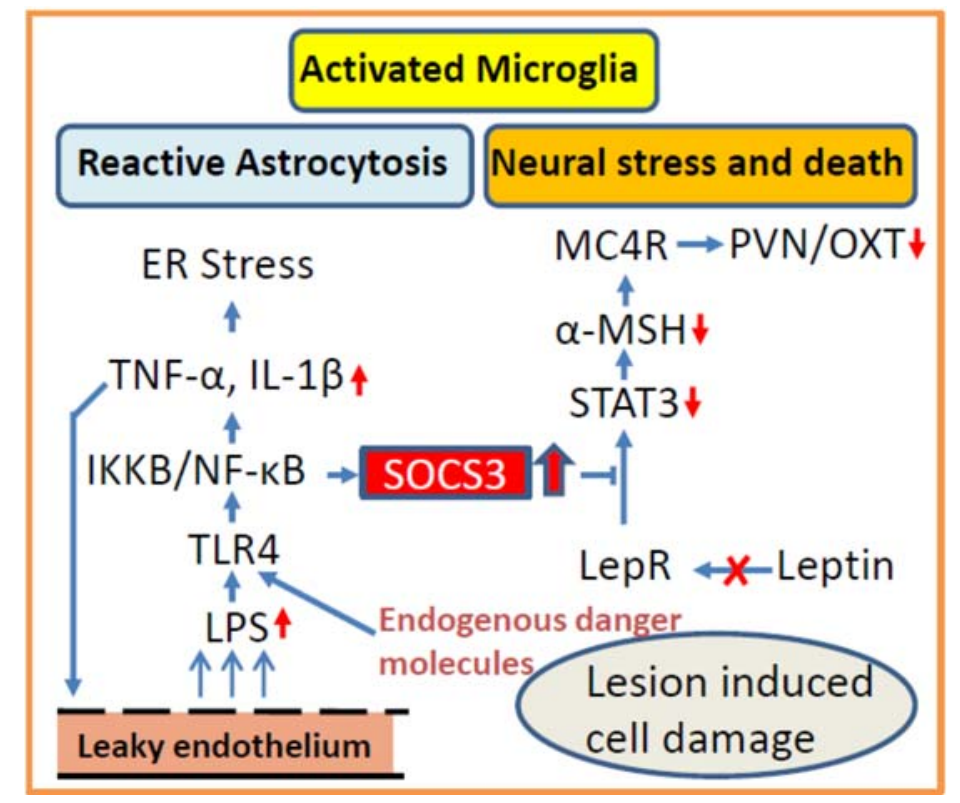

Figure 2. Schematic model of cellular and molecular components of neuroinflammation and repair mechanisms after brain surgery potentially affecting leptin receptor sites and melanocortin signaling resulting in disturbed energy balance. ER: endoplasmic reticulum; TNF- $\alpha$ : tumor necrosis factor alpha; IL-1 $\beta$ : interleukin 1 beta; IKKB:

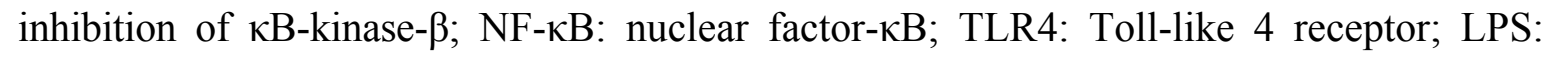
lipopolysaccharide; SOCS-3: suppressor of cytokine signaling 3; STAT3: signal transducer and activation of transcription 3; $\alpha-\mathrm{MSH}$ : alpha-melanocyte-stimulating hormone; MC4R: melanocortin-4 receptor; LepR: leptin receptor. 


\section{Pharmacological Interventions}

\subsection{Rodent Studies}

Drugs that mostly act through ARC signaling pathways (such as leptin) would not be likely candidates for reducing excess weight as the ARC is often involved in hypothalamic damage. More promising candidates are agents acting further "downstream" such as melanocortin (MC) receptor agonists that stimulate $\mathrm{MC}$ and are expressed in hypothalamic nuclei as well as extrahypothalamic and peripheral tissues [133], melanin-concentrating hormone-1 receptor antagonists that antagonize the strong orexigen melanin-concentrating hormone expressed in the lateral hypothalamus [134,135], and drugs that increase catecholaminergic signaling to stimulate energy expenditure [136,137]. Leptin resistance can be bypassed by MC 3/4 receptor agonist MTII in obese Zucker (fa/fa) rats, which are a genetic HO model with disturbed leptin signaling [138].

Recently, the CMHL rat model was used to test the efficacy of three pharmaceutical agents that act downstream of the mediobasal hypothalamus to reduce food intake and body weight. These agents include MTII, the glucagon-like peptide (GLP)-1 agonist exenatide and the psychomotor stimulant methylphenidate $[139,140]$. Both sham-lesioned and CMHL rats exhibited significant reductions in both food intake (lesion $-20.8 \%$, control $-13.7 \%$ ) and body weight when treated with exenatide relative to saline-controls [139]. Using a crossover design study, treatment with methylphenidate in both sham and CHML rats caused a significant decrease in food intake (CMHL $-23 \%, p=0.008$; control $-20 \%, p=0.002$ ) and body weight compared to saline-treated controls [140]. Finally, peripheral administration of MTII reduced food intake and body weight relative to sham-vehicle-treated controls $(p<0.05)$. Indirect calorimetry established that the effect of MTII was due to both a reduction in food intake, as well as an increase in energy expenditure [5,141].

\subsection{Studies in Humans}

Effective strategies to treat or prevent $\mathrm{HO}$ still need to be established as previous drug intervention studies were either too small or showed only moderate effects [29,49-56]. Treatment of hyperphagia and $\mathrm{HO}$ with the central nervous stimulant dextroamphetamine is reported to result in stabilization of weight gain but no weight loss [55,56]. Octreotide, a somatostatin analog, was reported to reduce both hyperinsulinemia and BMI in a double-blind placebo-controlled study; however, it supports weight stability only in patients with profound hyperinsulinemia and is limited by significant side effects [29]. Another attempt to treat hyperinsulinemia was combined diazoxide-metformin therapy; this was associated with reduced weight gain but significant side effects limited the enthusiasm after the initial pilot study [50]. A pilot study of caffeine and ephedrine given to three patients with HO resulted in a mean weight loss of $14 \%$ with two patients sustaining weight loss for at least two years; long term safety, particularly in the pediatric population, is unknown [49]. Reduction of energy expenditure in craniopharyngioma patients can be related to disturbed leptin signaling (see above) or hypothyroidism [51]. As patients with HO present commonly with panhypopituitarism including central hypothyroidism, it is necessary to treat central hypothyroidism appropriately yielding free thyroxine (FT4) levels in the upper normal range [142]. Tri-iodothyronine (T3) treatment aiming for supraphysiological T3 levels was considered by different groups [143,144]. Van Santen et al. [145] tested in one subject if 
switching treatment for central hypothyroidism to tri-iodothyronine (T3) monotherapy may be beneficial in increasing energy expenditure (thyroid hormone induced thermogenesis). However, T3 monotherapy was not effective as there was no change in BMI or energy expenditure assessed by sympathetic activity and brown adipose tissue thermogenesis.

Previous results of treating $\mathrm{HO}$ with a glucagon-like-peptide-1 receptor agonist (GLP1RA) in rats [139] and humans [146-148] are promising for conducting clinical trials in future. GLP-1 is secreted in response to ingestion of nutrients [149]. It is a key incretin that potentiates glucose-dependent insulin release and suppresses hepatic glucose output by suppressing glucagon secretion [150,151]. GLP-1 binds to receptors (GLP-1Rs) in the vagus as well as to appetite-related sites in the hindbrain (nucleus of the solitary tract, area postrema) and the hypothalamus (arcuate and dorsomedial nuclei) [152-156], which are areas that are not fully blocked from the peripheral circulation by the blood-brain barrier [150]. By binding to these receptors, GLP-1 functions as a satiety hormone, promoting reduced food intake and meal termination [153-156], as well as modulating activity in appetite- and reward-related brain areas [157]. Many anti-obesity drugs require intact hypothalamic signaling pathways for appetite inhibition, and, for such medications, weight reduction was poor for HO compared to uncomplicated obesity [54]. However, from a mechanistic standpoint GLPRAs might cause weight loss via intact hindbrain signaling pathways and thereby offer a desperately needed treatment option for HO, even in very obese HO subjects with severe hypothalamic damage [146-148]. Peripheral administration of GLP-1 or GLP1RA reduces blood glucose and energy intake in humans and rodents, and long-term treatment results in loss of body weight [158-175]. However, it is unknown whether GLP1RA treatment also affects energy expenditure and activity in subjects with hypothalamic lesions [176-179].

Further pharmacological approaches might include combinations of different drugs or newer anti-angiogenesis medication [180], in order to achieve persistent changes of energy homeostasis and negative energy balance.

\section{Summary}

In conclusion, hypothalamic obesity is a condition with extremely high morbidity. Mechanisms leading to the profoundly disturbed energy homeostasis are complex. Patients with hypothalamic lesions extending to nuclei located in the posterior hypothalamus have a particularly high risk for $\mathrm{HO}$ development. Standardized HO risk assessment using the HLS system may allow earlier identification of patients at risk and initiation of intervention strategies, which is critical as the strongest weight gain occurs during the first 12 months following surgery [25]. However, HO is extremely challenging to treat and effective strategies to treat or prevent $\mathrm{HO}$ still need to be established. Recent insights into the pathophysiology of lesion-induced HO might help to identify targets of promising obesity interventions in future.

\section{Conflicts of Interest}

The author declares no conflict of interest. 


\section{List of Abbreviations}

\begin{tabular}{|c|c|}
\hline$\alpha-\mathrm{MSH}$ & alpha-melanocyte-stimulating hormone \\
\hline ARC & arcuate nucleus \\
\hline BMI & body mass index \\
\hline CMHL & combined medial hypothalamic lesions \\
\hline $\mathrm{CP}$ & craniopharyngioma \\
\hline CVD & cardiovascular disease \\
\hline DHA & dorsal hypothalamic area \\
\hline $\mathrm{DMN}$ & dorsomedial nucleus \\
\hline fMRI & functional magnetic resonance imaging \\
\hline GLP-1 & glucagon-like peptide-1 \\
\hline HLS & hypothalamic lesion scoring \\
\hline $\mathrm{HO}$ & hypothalamic obesity \\
\hline IL & interleukin \\
\hline IKKB & inhibitor of nuclear factor kappa-B kinase subunit beta \\
\hline $\mathrm{MC}$ & melanocortin \\
\hline MC4R & melanocortin-4 receptor \\
\hline MSG & monosodium L-glutamate \\
\hline MTII & melanotan 2 \\
\hline $\mathrm{NF}-\kappa \mathrm{B}$ & nuclear factor kappa B \\
\hline OXT & oxytocin \\
\hline PVN & paraventricular nucleus \\
\hline SOCS-3 & suppressor of cytokine signaling-3 \\
\hline TLR4 & toll-like receptor-4 \\
\hline TNF- $\alpha$ & Tumor necrosis factor- $\alpha$ \\
\hline T2DM & type 2 diabetes mellitus \\
\hline $\mathrm{T} 3$ & tri-iodothyronine \\
\hline $\mathrm{T} 4$ & thyroxine \\
\hline $\mathrm{VMN}$ & ventromedial nucleus \\
\hline
\end{tabular}

\section{References}

1. Steinberger, J.; Daniels, S.R. Obesity, insulin resistance, diabetes, and cardiovascular risk in children: An american heart association scientific statement from the atherosclerosis, hypertension, and obesity in the young committee (council on cardiovascular disease in the young) and the diabetes committee (council on nutrition, physical activity, and metabolism). Circulation 2003, 107, 1448-1453.

2. Ogden, C.L.; Carroll, M.D.; Kit, B.K.; Flegal, K.M. Prevalence of obesity and trends in body mass index among us children and adolescents, 1999-2010. JAMA 2012, 307, 483-490.

3. May, A.L.; Kuklina, E.V.; Yoon, P.W. Prevalence of cardiovascular disease risk factors among us adolescents, 1999-2008. Pediatrics 2012, 129, 1035-1041. 
4. Freedman, D.S.; Mei, Z.; Srinivasan, S.R.; Berenson, G.S.; Dietz, W.H. Cardiovascular risk factors and excess adiposity among overweight children and adolescents: The bogalusa heart study. J. Pediatr. 2007, 150, 12-17.

5. Heymsfield, S.B.; Avena, N.M.; Baier, L.; Brantley, P.; Bray, G.A.; Burnett, L.C.; Butler, M.G.; Driscoll, D.J.; Egli, D.; Elmquist, J.; et al. Hyperphagia: Current concepts and future directions proceedings of the 2nd international conference on hyperphagia. Obesity (Silver Spring) 2014, 22, S1-S17.

6. Roth, C.L. Hypothalamic obesity in patients with craniopharyngioma: Profound changes of several weight regulatory circuits. Front. Endocrinol. (Lausanne) 2011, 2, 49.

7. Muller, H.L. Craniopharyngioma. Endocr. Rev. 2014, er20131115.

8. Goldstone, A.P. The hypothalamus, hormones, and hunger: Alterations in human obesity and illness. Prog. Brain Res. 2006, 153, 57-73.

9. Zegers, D.; van Hul, W.; van Gaal, L.F.; Beckers, S. Monogenic and complex forms of obesity: Insights from genetics reveal the leptin-melanocortin signaling pathway as a common player. Crit. Rev. Eukaryot. Gene Expr. 2012, 22, 325-343.

10. Cai, D. Neuroinflammation and neurodegeneration in overnutrition-induced diseases. Trends Endocrinol. Metab. 2013, 24, 40-47.

11. Farooqi, I.S. Monogenic human obesity syndromes. Prog. Brain Res. 2006, 153, 119-125.

12. Harwood-Nash, D.C. Neuroimaging of childhood craniopharyngioma. Pediatr. Neurosurg. 1994, 21, 2-10.

13. Dolecek, T.A.; Propp, J.M.; Stroup, N.E.; Kruchko, C. Cbtrus statistical report: Primary brain and central nervous system tumors diagnosed in the united states in 2005-2009. Neuro Oncol. 2012, 14, v1-v49.

14. Hankinson, T.C.; Fields, E.C.; Torok, M.R.; Beaty, B.L.; Handler, M.H.; Foreman, N.K.; O’Neill, B.R.; Liu, A.K. Limited utility despite accuracy of the national seer dataset for the study of craniopharyngioma. J. Neurooncol. 2012, 110, 271-278.

15. Ostrom, Q.T.; Gittleman, H.; Farah, P.; Ondracek, A.; Chen, Y.; Wolinsky, Y.; Stroup, N.E.; Kruchko, C.; Barnholtz-Sloan, J.S. Cbtrus statistical report: Primary brain and central nervous system tumors diagnosed in the united states in 2006-2010. Neuro Oncol. 2013, 15, ii1-ii56.

16. Muller, H.L. Consequences of craniopharyngioma surgery in children. J. Clin. Endocrinol. Metab. 2011, 96, 1981-1991.

17. Crom, D.B.; Smith, D.; Xiong, Z.; Onar, A.; Hudson, M.M.; Merchant, T.E.; Morris, E.B. Health status in long-term survivors of pediatric craniopharyngiomas. J. Neurosci. Nurs. 2010, 42, 323-328.

18. Anderson, C.A.; Wilkening, G.N.; Filley, C.M.; Reardon, M.S.; Kleinschmidt-DeMasters, B.K. Neurobehavioral outcome in pediatric craniopharyngioma. Pediatr. Neurosurg. 1997, 26, 255-260.

19. Muller, H.L.; Bruhnken, G.; Emser, A.; Faldum, A.; Etavard-Gorris, N.; Gebhardt, U.; Kolb, R.; Sorensen, N. Longitudinal study on quality of life in 102 survivors of childhood craniopharyngioma. Childs Nerv. Syst. 2005, 21, 975-980.

20. Erfurth, E.M. Endocrine aspects and sequel in patients with craniopharyngioma. J. Pediatr. Endocrinol. Metab. 2015, 28, 19-26. 
21. Olsson, D.S.; Andersson, E.; Bryngelsson, I.L.; Nilsson, A.G.; Johannsson, G. Excess mortality and morbidity in patients with craniopharyngioma, especially in patients with childhood onset: A population-based study in sweden. J. Clin. Endocrinol. Metab. 2015, 100, 467-474.

22. Sorva, R. Children with craniopharyngioma. Early growth failure and rapid postoperative weight gain. Acta Paediatr. Scand. 1988, 77, 587-592.

23. Muller, H.L.; Emser, A.; Faldum, A.; Bruhnken, G.; Etavard-Gorris, N.; Gebhardt, U.; Oeverink, R.; Kolb, R.; Sorensen, N. Longitudinal study on growth and body mass index before and after diagnosis of childhood craniopharyngioma. J. Clin. Endocrinol. Metab. 2004, 89, 3298-3305.

24. Muller, H.L.; Heinrich, M.; Bueb, K.; Etavard-Gorris, N.; Gebhardt, U.; Kolb, R.; Sorensen, N. Perioperative dexamethasone treatment in childhood craniopharyngioma-Influence on short-term and long-term weight gain. Exp. Clin. Endocrinol. Diabetes 2003, 111, 330-334.

25. Roth, C.L.; Eslamy, H.; Werny, D.; Elfers, C.; Shaffer, M.L.; Pihoker, C.; Ojemann, J.; Dobyns, W.B. Semiquantitative analysis of hypothalamic damage on mri predicts risk for hypothalamic obesity. Obesity (Silver Spring) 2015, 23, 1226-1233.

26. Daubenbuchel, A.M.; Hoffmann, A.; Gebhardt, U.; Warmuth-Metz, M.; Sterkenburg, A.S.; Muller, H.L. Hydrocephalus and hypothalamic involvement in pediatric patients with craniopharyngioma or cysts of rathke's pouch: Impact on long-term prognosis. Eur. J. Endocrinol. 2015, 172, 561-569.

27. Holmer, H.; Pozarek, G.; Wirfalt, E.; Popovic, V.; Ekman, B.; Bjork, J.; Erfurth, E.M. Reduced energy expenditure and impaired feeding-related signals but not high energy intake reinforces hypothalamic obesity in adults with childhood onset craniopharyngioma. J. Clin. Endocrinol. Metab. 2010, 95, 5395-5402.

28. Harz, K.J.; Muller, H.L.; Waldeck, E.; Pudel, V.; Roth, C. Obesity in patients with craniopharyngioma: Assessment of food intake and movement counts indicating physical activity. J. Clin. Endocrinol. Metab. 2003, 88, 5227-5231.

29. Lustig, R.H.; Hinds, P.S.; Ringwald-Smith, K.; Christensen, R.K.; Kaste, S.C.; Schreiber, R.E.; Rai, S.N.; Lensing, S.Y.; Wu, S.; Xiong, X. Octreotide therapy of pediatric hypothalamic obesity: A double-blind, placebo-controlled trial. J. Clin. Endocrinol. Metab. 2003, 88, 2586-2592.

30. Roth, C.; Wilken, B.; Hanefeld, F.; Schroter, W.; Leonhardt, U. Hyperphagia in children with craniopharyngioma is associated with hyperleptinaemia and a failure in the downregulation of appetite. Eur. J. Endocrinol. 1998, 138, 89-91.

31. Patel, L.; Cooper, C.D.; Quinton, N.D.; Butler, G.E.; Gill, M.S.; Jefferson, I.G.; Kibirige, M.S.; Price, D.A.; Shalet, S.M.; Wales, J.K.; et al. Serum leptin and leptin binding activity in children and adolescents with hypothalamic dysfunction. J. Pediatr. Endocrinol. Metab. 2002, 15, 963-971.

32. Shaikh, M.G.; Grundy, R.G.; Kirk, J.M. Hyperleptinaemia rather than fasting hyperinsulinaemia is associated with obesity following hypothalamic damage in children. Eur. J. Endocrinol. 2008, 159, 791-797. 
33. Guran, T.; Turan, S.; Bereket, A.; Akcay, T.; Unluguzel, G.; Bas, F.; Gunoz, H.; Saka, N.; Bundak, R.; Darendeliler, F.; et al. The role of leptin, soluble leptin receptor, resistin, and insulin secretory dynamics in the pathogenesis of hypothalamic obesity in children. Eur. J. Pediatr. 2009, 168, 1043-1048.

34. Simoneau-Roy, J.; O’Gorman, C.; Pencharz, P.; Adeli, K.; Daneman, D.; Hamilton, J. Insulin sensitivity and secretion in children and adolescents with hypothalamic obesity following treatment for craniopharyngioma. Clin. Endocrinol. (Oxf.) 2010, 72, 364-370.

35. Roth, C.L.; Enriori, P.J.; Gebhardt, U.; Hinney, A.; Muller, H.L.; Hebebrand, J.; Reinehr, T.; Cowley, M.A. Changes of peripheral alpha-melanocyte-stimulating hormone in childhood obesity. Metabolism 2010, 59, 186-194.

36. Roth, C.L.; Hunneman, D.H.; Gebhardt, U.; Stoffel-Wagner, B.; Reinehr, T.; Muller, H.L. Reduced sympathetic metabolites in urine of obese patients with craniopharyngioma. Pediatr. Res. 2007, 61, 496-501.

37. Roth, C.L.; Gebhardt, U.; Muller, H.L. Appetite-regulating hormone changes in patients with craniopharyngioma. Obesity (Silver Spring) 2011, 19, 36-42.

38. Muller, H.L.; Bueb, K.; Bartels, U.; Roth, C.; Harz, K.; Graf, N.; Korinthenberg, R.; Bettendorf, M.; Kuhl, J.; Gutjahr, P.; et al. Obesity after childhood craniopharyngioma-German multicenter study on pre-operative risk factors and quality of life. Klin. Padiatr. 2001, 213, 244-249.

39. Shaikh, M.G.; Grundy, R.G.; Kirk, J.M. Reductions in basal metabolic rate and physical activity contribute to hypothalamic obesity. J. Clin. Endocrinol. Metab. 2008, 93, 2588-2593.

40. Coutant, R.; Maurey, H.; Rouleau, S.; Mathieu, E.; Mercier, P.; Limal, J.M.; le Bouil, A. Defect in epinephrine production in children with craniopharyngioma: Functional or organic origin? J. Clin. Endocrinol. Metab. 2003, 88, 5969-5975.

41. Roth, C.L.; Blevins, J.E.; Ralston, M.; Elfers, C.; Ogimoto, K.; Kaiyala, K.J.; Morton, G.J. A novel rodent model that mimics the metabolic sequelae of obese craniopharyngioma patients. Pediatr. Res. 2011, 69, 230-236.

42. O’Gorman, C.S.; Simoneau-Roy, J.; Pencharz Mb, P.; Adeli, K.; Hamilton, J. Delayed ghrelin suppression following oral glucose tolerance test in children and adolescents with hypothalamic injury secondary to craniopharyngioma compared with obese controls. Int. J. Pediatr. Obes. 2011, 6, 285-288.

43. An, J.J.; Rhee, Y.; Kim, S.H.; Kim, D.M.; Han, D.H.; Hwang, J.H.; Jin, Y.J.; Cha, B.S.; Baik, J.H.; Lee, W.T.; et al. Peripheral effect of alpha-melanocyte-stimulating hormone on fatty acid oxidation in skeletal muscle. J. Biol. Chem. 2007, 282, 2862-2870.

44. Srinivasan, S.; Ogle, G.D.; Garnett, S.P.; Briody, J.N.; Lee, J.W.; Cowell, C.T. Features of the metabolic syndrome after childhood craniopharyngioma. J. Clin. Endocrinol. Metab. 2004, 89, 81-86.

45. Bulow, B.; Attewell, R.; Hagmar, L.; Malmstrom, P.; Nordstrom, C.H.; Erfurth, E.M. Postoperative prognosis in craniopharyngioma with respect to cardiovascular mortality, survival, and tumor recurrence. J. Clin. Endocrinol. Metab. 1998, 83, 3897-3904. 
46. Pereira, A.M.; Schmid, E.M.; Schutte, P.J.; Voormolen, J.H.; Biermasz, N.R.; van Thiel, S.W.; Corssmit, E.P.; Smit, J.W.; Roelfsema, F.; Romijn, J.A. High prevalence of long-term cardiovascular, neurological and psychosocial morbidity after treatment for craniopharyngioma. Clin. Endocrinol. (Oxf.) 2005, 62, 197-204.

47. Mong, S.; Pomeroy, S.L.; Cecchin, F.; Juraszek, A.; Alexander, M.E. Cardiac risk after craniopharyngioma therapy. Pediatr. Neurol. 2008, 38, 256-260.

48. Van Gaal, L.F.; Mertens, I.L.; de Block, C.E. Mechanisms linking obesity with cardiovascular disease. Nature 2006, 444, 875-880.

49. Greenway, F.L.; Bray, G.A. Treatment of hypothalamic obesity with caffeine and ephedrine. Endocr. Pract. 2008, 14, 697-703.

50. Hamilton, J.K.; Conwell, L.S.; Syme, C.; Ahmet, A.; Jeffery, A.; Daneman, D. Hypothalamic obesity following craniopharyngioma surgery: Results of a pilot trial of combined diazoxide and metformin therapy. Int. J. Pediatr. Endocrinol. 2011, 2011, 417949.

51. Bereket, A.; Kiess, W.; Lustig, R.H.; Muller, H.L.; Goldstone, A.P.; Weiss, R.; Yavuz, Y.; Hochberg, Z. Hypothalamic obesity in children. Obes. Rev. 2012, 13, 780-798.

52. Lustig, R.H. Hypothalamic obesity after craniopharyngioma: Mechanisms, diagnosis, and treatment. Front. Endocrinol. (Lausanne) 2011, 2, 60.

53. Lustig, R.H. Hypothalamic obesity: Causes, consequences, treatment. Pediatr. Endocrinol. Rev. 2008, 6, 220-227.

54. Danielsson, P.; Janson, A.; Norgren, S.; Marcus, C. Impact sibutramine therapy in children with hypothalamic obesity or obesity with aggravating syndromes. J. Clin. Endocrinol. Metab. 2007, 92, 4101-4106.

55. Mason, P.W.; Krawiecki, N.; Meacham, L.R. The use of dextroamphetamine to treat obesity and hyperphagia in children treated for craniopharyngioma. Arch. Pediatr. Adolesc. Med. 2002, 156, 887-892.

56. Ismail, D.; O'Connell, M.A.; Zacharin, M.R. Dexamphetamine use for management of obesity and hypersomnolence following hypothalamic injury. J. Pediatr. Endocrinol. Metab. 2006, 19, 129-134.

57. Elowe-Gruau, E.; Beltrand, J.; Brauner, R.; Pinto, G.; Samara-Boustani, D.; Thalassinos, C.; Busiah, K.; Laborde, K.; Boddaert, N.; Zerah, M.; et al. Childhood craniopharyngioma: Hypothalamus-sparing surgery decreases the risk of obesity. J. Clin. Endocrinol. Metab. 2013, 98, 2376-2382.

58. Muller, H.L.; Gebhardt, U.; Teske, C.; Faldum, A.; Zwiener, I.; Warmuth-Metz, M.; Pietsch, T.; Pohl, F.; Sorensen, N.; Calaminus, G. Post-operative hypothalamic lesions and obesity in childhood craniopharyngioma: Results of the multinational prospective trial kraniopharyngeom 2000 after 3-year follow-up. Eur. J. Endocrinol. 2011, 165, 17-24.

59. Roth, C.L.; Eslamy, H.; Pihoker, C.; Elfers, C.; Ojemann, J.; Dobyns, W.B. Semi-quantitative analysis of hypothalamic damage on mri predicts risk for hypothalamic obesity. Obesity 2014, 23, 1226-1233.

60. Muller, H.L. Childhood craniopharyngioma - Current concepts in diagnosis, therapy and follow-up. Nat. Rev. Endocrinol. 2010, 6, 609-618. 
61. Muller, H.L. Childhood craniopharyngioma. Recent advances in diagnosis, treatment and follow-up. Horm. Res. 2008, 69, 193-202.

62. Batterham, R.L.; ffytche, D.H.; Rosenthal, J.M.; Zelaya, F.O.; Barker, G.J.; Withers, D.J.; Williams, S.C. Pyy modulation of cortical and hypothalamic brain areas predicts feeding behaviour in humans. Nature 2007, 450, 106-109.

63. Figlewicz, D.P.; Benoit, S.C. Insulin, leptin, and food reward: Update 2008. Am. J. Physiol. Regul. Integr. Comp. Physiol. 2009, 296, R9-R19.

64. Morton, G.J.; Cummings, D.E.; Baskin, D.G.; Barsh, G.S.; Schwartz, M.W. Central nervous system control of food intake and body weight. Nature 2006, 443, 289-295.

65. Bouret, S.G.; Draper, S.J.; Simerly, R.B. Trophic action of leptin on hypothalamic neurons that regulate feeding. Science 2004, 304, 108-110.

66. Glavas, M.M.; Joachim, S.E.; Draper, S.J.; Smith, M.S.; Grove, K.L. Melanocortinergic activation by melanotan ii inhibits feeding and increases uncoupling protein 1 messenger ribonucleic acid in the developing rat. Endocrinology 2007, 148, 3279-3287.

67. Mihaly, E.; Fekete, C.; Legradi, G.; Lechan, R.M. Hypothalamic dorsomedial nucleus neurons innervate thyrotropin-releasing hormone-synthesizing neurons in the paraventricular nucleus. Brain Res. 2001, 891, 20-31.

68. van Swieten, M.M.; Pandit, R.; Adan, R.A.; van der Plasse, G. The neuroanatomical function of leptin in the hypothalamus. J. Chem. Neuroanat. 2014, 61-62, 207-220.

69. Douglas, A.J.; Johnstone, L.E.; Leng, G. Neuroendocrine mechanisms of change in food intake during pregnancy: A potential role for brain oxytocin. Physiol. Behav. 2007, 91, 352-365.

70. Matarazzo, V.; Schaller, F.; Nedelec, E.; Benani, A.; Penicaud, L.; Muscatelli, F.; Moyse, E.; Bauer, S. Inactivation of socs3 in the hypothalamus enhances the hindbrain response to endogenous satiety signals via oxytocin signaling. J. Neurosci. 2012, 32, 17097-17107.

71. Munzberg, H.; Flier, J.S.; Bjorbaek, C. Region-specific leptin resistance within the hypothalamus of diet-induced obese mice. Endocrinology 2004, 145, 4880-4889.

72. Maejima, Y.; Sedbazar, U.; Suyama, S.; Kohno, D.; Onaka, T.; Takano, E.; Yoshida, N.; Koike, M.; Uchiyama, Y.; Fujiwara, K.; et al. Nesfatin-1-regulated oxytocinergic signaling in the paraventricular nucleus causes anorexia through a leptin-independent melanocortin pathway. Cell Metab. 2009, 10, 355-365.

73. Holder, J.L., Jr.; Butte, N.F.; Zinn, A.R. Profound obesity associated with a balanced translocation that disrupts the sim1 gene. Hum. Mol. Genet. 2000, 9, 101-108.

74. Swaab, D.F.; Purba, J.S.; Hofman, M.A. Alterations in the hypothalamic paraventricular nucleus and its oxytocin neurons (putative satiety cells) in prader-willi syndrome: A study of five cases. $J$. Clin. Endocrinol. Metab. 1995, 80, 573-579.

75. Hochberg, I.; Hochberg, Z. Expanding the definition of hypothalamic obesity. Obes. Rev. 2010, 11, 709-721.

76. Cohen, M.; Syme, C.; McCrindle, B.W.; Hamilton, J. Autonomic nervous system balance in children and adolescents with craniopharyngioma and hypothalamic obesity. Eur. J. Endocrinol. 2013, 168, 845-852. 
77. Kitano, M.; Taneda, M. Extended transsphenoidal surgery for suprasellar craniopharyngiomas: Infrachiasmatic radical resection combined with or without a suprachiasmatic trans-lamina terminalis approach. Surg. Neurol. 2009, 71, 290-298, discussion 298.

78. Chakrabarti, I.; Amar, A.P.; Couldwell, W.; Weiss, M.H. Long-term neurological, visual, and endocrine outcomes following transnasal resection of craniopharyngioma. J. Neurosurg. 2005, $102,650-657$.

79. Roth, C.L.; Aylward, E.; Liang, O.; Kleinhans, N.M.; Pauley, G.; Schur, E.A. Functional neuroimaging in craniopharyngioma: A useful tool to better understand hypothalamic obesity? Obes. Facts 2012, 5, 243-253.

80. Ozyurt, J.; Lorenzen, A.; Gebhardt, U.; Warmuth-Metz, M.; Muller, H.L.; Thiel, C.M. Remote effects of hypothalamic lesions in the prefrontal cortex of craniopharygioma patients. Neurobiol. Learn. Mem. 2014, 111, 71-80.

81. DeVile, C.J.; Grant, D.B.; Hayward, R.D.; Stanhope, R. Growth and endocrine sequelae of craniopharyngioma. Arch. Dis. Child. 1996, 75, 108-114.

82. Pascual, J.M.; Carrasco, R.; Prieto, R.; Gonzalez-Llanos, F.; Alvarez, F.; Roda, J.M. Craniopharyngioma classification. J. Neurosurg. 2008, 109, 1180-1182.

83. Daousi, C.; Dunn, A.J.; Foy, P.M.; MacFarlane, I.A.; Pinkney, J.H. Endocrine and neuroanatomic features associated with weight gain and obesity in adult patients with hypothalamic damage. Am. J. Med. 2005, 118, 45-50.

84. De Vile, C.J.; Grant, D.B.; Hayward, R.D.; Kendall, B.E.; Neville, B.G.; Stanhope, R. Obesity in childhood craniopharyngioma: Relation to post-operative hypothalamic damage shown by magnetic resonance imaging. J. Clin. Endocrinol. Metable 1996, 81, 2734-2737.

85. Van Gompel, J.J.; Nippoldt, T.B.; Higgins, D.M.; Meyer, F.B. Magnetic resonance imaging-graded hypothalamic compression in surgically treated adult craniopharyngiomas determining postoperative obesity. Neurosurg. Focus 2010, 28, E3.

86. Puget, S.; Garnett, M.; Wray, A.; Grill, J.; Habrand, J.L.; Bodaert, N.; Zerah, M.; Bezerra, M.; Renier, D.; Pierre-Kahn, A.; et al. Pediatric craniopharyngiomas: Classification and treatment according to the degree of hypothalamic involvement. J. Neurosurg. 2007, 106, 3-12.

87. Ahmet, A.; Blaser, S.; Stephens, D.; Guger, S.; Rutkas, J.T.; Hamilton, J. Weight gain in craniopharyngioma - A model for hypothalamic obesity. J. Pediatr. Endocrinol. Metab. 2006, 19, $121-127$.

88. Elfers, C.; Ralston, M.; Roth, C.L. Studies of different female rat models of hypothalamic obesity. J. Pediatr. Endocrinol. Metab. 2011, 24, 131-137.

89. Tokunaga, K.; Matsuzawa, Y.; Fujioka, S.; Kobatake, T.; Keno, Y.; Odaka, H.; Matsuo, T.; Tarui, S. Pvn-lesioned obese rats maintain ambulatory activity and its circadian rhythm. Brain Res. Bull. 1991, 26, 393-396.

90. Tokunaga, K.; Bray, G.A.; Matsuzawa, Y. Improved yield of obese rats using a double coordinate system to locate the ventromedial or paraventricular nucleus. Brain Res. Bull. 1993, 32, 191-194.

91. Olney, J.W. Brain lesions, obesity, and other disturbances in mice treated with monosodium glutamate. Science 1969, 164, 719-721. 
92. Schoelch, C.; Hubschle, T.; Schmidt, I.; Nuesslein-Hildesheim, B. Msg lesions decrease body mass of suckling-age rats by attenuating circadian decreases of energy expenditure. Am. J. Physiol. Endocrinol. Metab. 2002, 283, E604-E611.

93. Kubota, A.; Nakagawa, Y.; Igarashi, Y. Studies of gene expression in liver of insulin-like growth factor (igf)-i, igf binding protein-3 and growth hormone (gh) receptor/gh binding protein in rats treated neonatally with monosodium glutamate. Horm. Metab. Res. 1994, 26, 497-503.

94. De Souza, C.T.; Nunes, W.M.; Gobatto, C.A.; de Mello, M.A. Insulin secretion in monosodium glutamate (msg) obese rats submitted to aerobic exercise training. Physiol. Chem. Phys. Med. NMR 2003, 35, 43-53.

95. Perello, M.; Moreno, G.; Gaillard, R.C.; Spinedi, E. Glucocorticoid-dependency of increased adiposity in a model of hypothalamic obesity. Neuro Endocrinol. Lett. 2004, 25, 119-126.

96. Balbo, S.L.; Bonfleur, M.L.; Carneiro, E.M.; Amaral, M.E.; Filiputti, E.; Mathias, P.C. Parasympathetic activity changes insulin response to glucose and neurotransmitters. Diabetes Metab. 2002, 28, 3S13-17; discussion 13S108-112.

97. Bonfleur, M.L.; Borck, P.C.; Ribeiro, R.A.; Caetano, L.C.; Soares, G.M.; Carneiro, E.M.; Balbo, S.L. Improvement in the expression of hepatic genes involved in fatty acid metabolism in obese rats supplemented with taurine. Life Sci. 2015, 135, 15-21.

98. Leite, N.C.; Montes, E.G.; Fisher, S.V.; Cancian, C.R.; de Oliveira, J.C.; Martins-Pinge, M.C.; Kanunfre, C.C.; Souza, K.L.; Grassiolli, S. Splenectomy attenuates obesity and decreases insulin hypersecretion in hypothalamic obese rats. Metabolism 2015, 64, 1122-1133.

99. Tomankova, V.; Liskova, B.; Skalova, L.; Bartikova, H.; Bousova, I.; Jourova, L.; Anzenbacher, P.; Ulrichova, J.; Anzenbacherova, E. Altered cytochrome p450 activities and expression levels in the liver and intestines of the monosodium glutamate-induced mouse model of human obesity. Life Sci. 2015, 133, 15-20.

100. Poletto, A.C.; David-Silva, A.; Yamamoto, A.P.; Machado, U.F.; Furuya, D.T. Reduced slc2a4/glut4 expression in subcutaneous adipose tissue of monosodium glutamate obese mice is recovered after atorvastatin treatment. Diabetol. Metab. Syndr. 2015, 7, 18.

101. Lubaczeuski, C.; Balbo, S.L.; Ribeiro, R.A.; Vettorazzi, J.F.; Santos-Silva, J.C.; Carneiro, E.M.; Bonfleur, M.L. Vagotomy ameliorates islet morphofunction and body metabolic homeostasis in msg-obese rats. Braz. J. Med. Biol. Res. 2015, 48, 447-457.

102. Guimaraes, E.D.; de Caires Junior, L.C.; Musso, C.M.; Macedo de Almeida, M.; Goncalves, C.F.; Pettersen, K.G.; Paes, S.T.; Gonzalez Garcia, R.M.; de Freitas Mathias, P.C.; Torrezan, R.; et al. Altered behavior of adult obese rats by monosodium L-glutamate neonatal treatment is related to hypercorticosteronemia and activation of hypothalamic erk1 and erk2. Nutr. Neurosci. 2015, doi:10.1179/1476830515Y.0000000004.

103. Dolnikoff, M.; Martin-Hidalgo, A.; Machado, U.F.; Lima, F.B.; Herrera, E. Decreased lipolysis and enhanced glycerol and glucose utilization by adipose tissue prior to development of obesity in monosodium glutamate (msg) treated-rats. Int. J. Obes. Relat. Metab. Disord. 2001, 25, 426-433.

104. Lucas, D.R.; Newhouse, J.P. The toxic effect of sodium l-glutamate on the inner layers of the retina. AMA Arch. Ophthalmol. 1957, 58, 193-201. 
105. Smyth, C.E.; Natarajan, M.; Wilkinson, M. Neonatal hypothalamic c-fos expression in an excitotoxicity-induced model of precocious puberty. Brain Res. Dev. Brain Res. 1997, 104, $153-162$.

106. Young, E.; Olney, J.; Akil, H. Selective alterations of opiate receptor subtypes in monosodium glutamate-treated rats. J. Neurochem. 1983, 40, 1558-1564.

107. Mutlu, L.K.; Woiciechowsky, C.; Bechmann, I. Inflammatory response after neurosurgery. Best Pract. Res. Clin. Anaesthesiol. 2004, 18, 407-424.

108. Martelli, C.; Iavarone, F.; Vincenzoni, F.; Rossetti, D.V.; D’Angelo, L.; Tamburrini, G.; Caldarelli, M.; di Rocco, C.; Messana, I.; Castagnola, M.; et al. Proteomic characterization of pediatric craniopharyngioma intracystic fluid by lc-ms top-down/bottom-up integrated approaches. Electrophoresis 2014, 35, 2172-2183.

109. Pettorini, B.L.; Inzitari, R.; Massimi, L.; Tamburrini, G.; Caldarelli, M.; Fanali, C.; Cabras, T.; Messana, I.; Castagnola, M.; di Rocco, C. The role of inflammation in the genesis of the cystic component of craniopharyngiomas. Childs Nerv. Syst. 2010, 26, 1779-1784.

110. Mori, M.; Takeshima, H.; Kuratsu, J. Expression of interleukin-6 in human craniopharyngiomas: A possible inducer of tumor-associated inflammation. Int. J. Mol. Med. 2004, 14, 505-509.

111. Thaler, J.P.; Yi, C.X.; Schur, E.A.; Guyenet, S.J.; Hwang, B.H.; Dietrich, M.O.; Zhao, X.; Sarruf, D.A.; Izgur, V.; Maravilla, K.R.; et al. Obesity is associated with hypothalamic injury in rodents and humans. J. Clin. Investig. 2012, 122, 153-162.

112. Choi, S.; Sparks, R.; Clay, M.; Dallman, M.F. Rats with hypothalamic obesity are insensitive to central leptin injections. Endocrinology 1999, 140, 4426-4433.

113. Milanski, M.; Degasperi, G.; Coope, A.; Morari, J.; Denis, R.; Cintra, D.E.; Tsukumo, D.M.; Anhe, G.; Amaral, M.E.; Takahashi, H.K.; et al. Saturated fatty acids produce an inflammatory response predominantly through the activation of tlr4 signaling in hypothalamus: Implications for the pathogenesis of obesity. J. Neurosci. 2009, 29, 359-370.

114. Thaler, J.P.; Schwartz, M.W. Minireview: Inflammation and obesity pathogenesis: The hypothalamus heats up. Endocrinology 2010, 151, 4109-4115.

115. Oh, I.S.; Thaler, J.P.; Ogimoto, K.; Wisse, B.E.; Morton, G.J.; Schwartz, M.W. Central administration of interleukin-4 exacerbates hypothalamic inflammation and weight gain during high-fat feeding. Am. J. Physiol. Endocrinol. Metab. 2010, 299, E47-E53.

116. Thaler, J.P.; Choi, S.J.; Schwartz, M.W.; Wisse, B.E. Hypothalamic inflammation and energy homeostasis: Resolving the paradox. Front. Neuroendocrinol. 2010, 31, 79-84.

117. El-Haschimi, K.; Pierroz, D.D.; Hileman, S.M.; Bjorbaek, C.; Flier, J.S. Two defects contribute to hypothalamic leptin resistance in mice with diet-induced obesity. J. Clin. Investig. 2000, 105, 1827-1832.

118. Savastano, D.M.; Covasa, M. Adaptation to a high-fat diet leads to hyperphagia and diminished sensitivity to cholecystokinin in rats. J. Nutr. 2005, 135, 1953-1959.

119. Posey, K.A.; Clegg, D.J.; Printz, R.L.; Byun, J.; Morton, G.J.; Vivekanandan-Giri, A.; Pennathur, S.; Baskin, D.G.; Heinecke, J.W.; Woods, S.C.; et al. Hypothalamic proinflammatory lipid accumulation, inflammation, and insulin resistance in rats fed a high-fat diet. Am. J. Physiol. Endocrinol. Metab. 2009, 296, E1003-E1012. 
120. Zhang, Y.; Scarpace, P.J. Circumventing central leptin resistance: Lessons from central leptin and pomc gene delivery. Peptides 2006, 27, 350-364.

121. Thaler, J.P.; Choi, S.J.; Sajan, M.P.; Ogimoto, K.; Nguyen, H.T.; Matsen, M.; Benoit, S.C.; Wisse, B.E.; Farese, R.V.; Schwartz, M.W. Atypical protein kinase c activity in the hypothalamus is required for lipopolysaccharide-mediated sickness responses. Endocrinology 2009, 150, 5362-5372.

122. Thaler, J.; Yi, C.X.; Schur, E.; Guyenet, S.; Hwang, B.; Dietrich, M.; Zhao, X.; Sarruf, D.A.; Izgur, V.; Maravilla, K.; et al. Evidence that obesity is associated with hypothalamic injury in rodent models and humans. J. Clin. Investig. 2012, 122, 153-162.

123. Wisse, B.E.; Schwartz, M.W. Does hypothalamic inflammation cause obesity? Cell Metab. 2009, 10, 241-242.

124. Velloso, L.A. The brain is the conductor: Diet-induced inflammation overlapping physiological control of body mass and metabolism. Arq. Bras. Endocrinol. Metabol. 2009, 53, 151-158.

125. Horvath, T.L.; Sarman, B.; Garcia-Caceres, C.; Enriori, P.J.; Sotonyi, P.; Shanabrough, M.; Borok, E.; Argente, J.; Chowen, J.A.; Perez-Tilve, D.; et al. Synaptic input organization of the melanocortin system predicts diet-induced hypothalamic reactive gliosis and obesity. Proc. Natl. Acad. Sci. USA 2010, 107, 14875-14880.

126. Cazettes, F.; Cohen, J.I.; Yau, P.L.; Talbot, H.; Convit, A. Obesity-mediated inflammation may damage the brain circuit that regulates food intake. Brain Res. 2011, 1373, 101-109.

127. Ren, K.; Torres, R. Role of interleukin-1beta during pain and inflammation. Brain Res. Rev. 2009, $60,57-64$.

128. Csuka, E.; Morganti-Kossmann, M.C.; Lenzlinger, P.M.; Joller, H.; Trentz, O.; Kossmann, T. Il-10 levels in cerebrospinal fluid and serum of patients with severe traumatic brain injury: Relationship to il-6, tnf-alpha, tgf-beta1 and blood-brain barrier function. J. Neuroimmunol. 1999, 101, 211-221.

129. Kossmann, T.; Hans, V.H.; Imhof, H.G.; Stocker, R.; Grob, P.; Trentz, O.; Morganti-Kossmann, C. Intrathecal and serum interleukin-6 and the acute-phase response in patients with severe traumatic brain injuries. Shock 1995, 4, 311-317.

130. Beamer, N.B.; Coull, B.M.; Clark, W.M.; Hazel, J.S.; Silberger, J.R. Interleukin-6 and interleukin-1 receptor antagonist in acute stroke. Ann. Neurol 1995, 37, 800-805.

131. Denis, R.G.; Arruda, A.P.; Romanatto, T.; Milanski, M.; Coope, A.; Solon, C.; Razolli, D.S.; Velloso, L.A. Tnf-alpha transiently induces endoplasmic reticulum stress and an incomplete unfolded protein response in the hypothalamus. Neuroscience 2010, 170, 1035-1044.

132. Mallard, C. Innate immune regulation by toll-like receptors in the brain. ISRN Neurol 2012, 2012, 701950.

133. Gautron, L.; Lee, C.; Funahashi, H.; Friedman, J.; Lee, S.; Elmquist, J. Melanocortin-4 receptor expression in a vago-vagal circuitry involved in postprandial functions. J. Comp. Neurol. 2010, 518, 6-24.

134. Borowsky, B.; Durkin, M.M.; Ogozalek, K.; Marzabadi, M.R.; DeLeon, J.; Lagu, B.; Heurich, R.; Lichtblau, H.; Shaposhnik, Z.; Daniewska, I.; et al. Antidepressant, anxiolytic and anorectic effects of a melanin-concentrating hormone-1 receptor antagonist. Nat. Med. 2002, 8, 825-830. 
135. Nair, S.G.; Adams-Deutsch, T.; Pickens, C.L.; Smith, D.G.; Shaham, Y. Effects of the mch1 receptor antagonist snap 94847 on high-fat food-reinforced operant responding and reinstatement of food seeking in rats. Psychopharmacology (Berl.) 2009, 205, 129-140.

136. Billes, S.K.; Cowley, M.A. Inhibition of dopamine and norepinephrine reuptake produces additive effects on energy balance in lean and obese mice. Neuropsychopharmacology 2007, 32, 822-834.

137. Arch, J.R. The discovery of drugs for obesity, the metabolic effects of leptin and variable receptor pharmacology: Perspectives from beta3-adrenoceptor agonists. Naunyn Schmiedebergs Arch. Pharmacol. 2008, 378, 225-240.

138. Cettour-Rose, P.; Rohner-Jeanrenaud, F. The leptin-like effects of 3-d peripheral administration of a melanocortin agonist are more marked in genetically obese zucker (fa/fa) than in lean rats. Endocrinology 2002, 143, 2277-2283.

139. Elfers, C.T.; Simmons, J.H.; Roth, C.L. Glucagon-like peptide-1 agonist exendin-4 leads to reduction of weight and caloric intake in a rat model of hypothalamic obesity. Horm. Res. Paediatr. 2012, 78, 47-53.

140. Elfers, C.T.; Roth, C.L. Effects of methylphenidate on weight gain and food intake in hypothalamic obesity. Front. Endocrinol. (Lausanne) 2011, 2, 78.

141. Roth, C.L.; Elfers, C.T.; Morton, G.J. A Model of Disturbed Weight Regulatory Pathways in Hypothalamic Obesity. In Proceedings of the Abstract NIH NIDDK Scientific Workshop- Rare Syndromic Body Fat Disorders, Bethesda, MD, USA, 1-2 March 2012.

142. Li, G.M.; Sun, X.J.; Shao, P. Postoperative pituitary hormonal disturbances and hormone replacement therapy time and dosage in children with craniopharyngiomas. Chin. Med. J. (Engl.) 2008, 121, 2077-2082.

143. Fernandes, J.K.; Klein, M.J.; Ater, J.L.; Kuttesch, J.F.; Vassilopoulou-Sellin, R. Triiodothyronine supplementation for hypothalamic obesity. Metabolism 2002, 51, 1381-1383.

144. Page-Wilson, G.; Wardlaw, S.L.; Khandji, A.G.; Korner, J. Hypothalamic obesity in patients with craniopharyngioma: Treatment approaches and the emerging role of gastric bypass surgery. Pituitary 2012, 15, 84-92.

145. van Santen, H.M.; Schouten-Meeteren, A.Y.; Serlie, M.; Meijneke, R.W.; van Trotsenburg, A.S.; Verberne, H.; Holleman, F.; Fliers, E. Effects of t3 treatment on brown adipose tissue and energy expenditure in a patient with craniopharyngioma and hypothalamic obesity. J. Pediatr. Endocrinol. Metab. 2015, 28, 53-57.

146. Simmons, J.H.; Shoemaker, A.H.; Roth, C.L. Treatment with glucagon-like peptide-1 agonist exendin-4 in a patient with hypothalamic obesity secondary to intracranial tumor. Horm. Res. Paediatr. 2012, 78, 54-58.

147. Kelly, A.S.; Rudser, K.D.; Nathan, B.M.; Fox, C.K.; Metzig, A.M.; Coombes, B.J.; Fitch, A.K.; Bomberg, E.M.; Abuzzahab, M.J. The effect of glucagon-like peptide-1 receptor agonist therapy on body mass index in adolescents with severe obesity: A randomized, placebo-controlled, clinical trial. JAMA Pediatr. 2013, 167, 355-360.

148. Zoicas, F.; Droste, M.; Mayr, B.; Buchfelder, M.; Schofl, C. Glp-1 analogues as a new treatment option for hypothalamic obesity in adults: Report of nine cases. Eur. J. Endocrinol. 2013, 168, 699-706. 
149. Drucker, D.J.; Nauck, M.A. The incretin system: Glucagon-like peptide-1 receptor agonists and dipeptidyl peptidase-4 inhibitors in type 2 diabetes. Lancet 2006, 368, 1696-1705.

150. Holst, J.J. Incretin hormones and the satiation signal. Int. J. Obes. (Lond.) 2013, 37, 1161-1168.

151. Li, N.; Lu, J.; Willars, G.B. Allosteric modulation of the activity of the glucagon-like peptide-1 (glp-1) metabolite glp-1 9-36 amide at the glp-1 receptor. PLOS ONE 2012, 7, e47936.

152. Secher, A.; Jelsing, J.; Baquero, A.F.; Hecksher-Sorensen, J.; Cowley, M.A.; Dalboge, L.S.; Hansen, G.; Grove, K.L.; Pyke, C.; Raun, K.; et al. The arcuate nucleus mediates glp-1 receptor agonist liraglutide-dependent weight loss. J. Clin. Investig. 2014, 124, 4473-4488.

153. Bloom, S.; Wynne, K.; Chaudhri, O. Gut feeling-The secret of satiety? Clin. Med. 2005, 5, $147-152$.

154. Bojanowska, E. Physiology and pathophysiology of glucagon-like peptide-1 (glp-1): The role of glp-1 in the pathogenesis of diabetes mellitus, obesity, and stress. Med. Sci. Monit. 2005, 11, RA271-RA278.

155. Gutzwiller, J.P.; Degen, L.; Heuss, L.; Beglinger, C. Glucagon-like peptide 1 (glp-1) and eating. Physiol. Behav. 2004, 82, 17-19.

156. Ma, X.; Bruning, J.; Ashcroft, F.M. Glucagon-like peptide 1 stimulates hypothalamic proopiomelanocortin neurons. J. Neurosci. 2007, 27, 7125-7129.

157. Van Bloemendaal, L.; RG, I.J.; Ten Kulve, J.S.; Barkhof, F.; Konrad, R.J.; Drent, M.L.; Veltman, D.J.; Diamant, M. Glp-1 receptor activation modulates appetite- and reward-related brain areas in humans. Diabetes 2014, 63, 4186-4196.

158. Ottney, A. Glucagon-like peptide-1 receptor agonists for weight loss in adult patients without diabetes. Am. J. Health Syst. Pharm. 2013, 70, 2097-2103.

159. Vilsboll, T.; Christensen, M.; Junker, A.E.; Knop, F.K.; Gluud, L.L. Effects of glucagon-like peptide-1 receptor agonists on weight loss: Systematic review and meta-analyses of randomised controlled trials. BMJ 2012, 344, d7771.

160. Gedulin, B.R.; Nikoulina, S.E.; Smith, P.A.; Gedulin, G.; Nielsen, L.L.; Baron, A.D.; Parkes, D.G.; Young, A.A. Exenatide (exendin-4) improves insulin sensitivity and \{beta\}-cell mass in insulin-resistant obese fa/fa zucker rats independent of glycemia and body weight. Endocrinology 2005, 146, 2069-2076.

161. Buse, J.B.; Nauck, M.; Forst, T.; Sheu, W.H.; Shenouda, S.K.; Heilmann, C.R.; Hoogwerf, B.J.; Gao, A.; Boardman, M.K.; Fineman, M.; et al. Exenatide once weekly versus liraglutide once daily in patients with type 2 diabetes (duration-6): A randomised, open-label study. Lancet 2013, 381, 117-124.

162. Aroda, V.R.; Ratner, R. The safety and tolerability of glp-1 receptor agonists in the treatment of type 2 diabetes: A review. Diabetes Metab. Res. Rev. 2011, 27, 528-542.

163. Pinelli, N.R.; Hurren, K.M. Efficacy and safety of long-acting glucagon-like peptide-1 receptor agonists compared with exenatide twice daily and sitagliptin in type 2 diabetes mellitus: A systematic review and meta-analysis. Ann. Pharm. 2011, 45, 850-860.

164. Stolar, M.W.; Grimm, M.; Chen, S. Comparison of extended release glp-1 receptor agonist therapy versus sitagliptin in the management of type 2 diabetes. Diabetes Metab. Syndr. Obes. 2013, 6, 435-444. 
165. Senda, M.; Ogawa, S.; Nako, K.; Okamura, M.; Sakamoto, T.; Ito, S. The glucagon-like peptide-1 analog liraglutide suppresses ghrelin and controls diabetes in a patient with prader-willi syndrome. Endocr. J. 2012, 59, 889-894.

166. Linnebjerg, H.; Kothare, P.A.; Skrivanek, Z.; de la Pena, A.; Atkins, M.; Ernest, C.S.; Trautmann, M.E. Exenatide: Effect of injection time on postprandial glucose in patients with type 2 diabetes. Diabet Med. 2006, 23, 240-245.

167. Norwood, P.; Liutkus, J.F.; Haber, H.; Pintilei, E.; Boardman, M.K.; Trautmann, M.E. Safety of exenatide once weekly in patients with type 2 diabetes mellitus treated with a thiazolidinedione alone or in combination with metformin for 2 years. Clin. Ther. 2012, 34, 2082-2090.

168. Inagaki, N.; Atsumi, Y.; Oura, T.; Saito, H.; Imaoka, T. Efficacy and safety profile of exenatide once weekly compared with insulin once daily in japanese patients with type 2 diabetes treated with oral antidiabetes drug(s): Results from a 26-week, randomized, open-label, parallel-group, multicenter, noninferiority study. Clin. Ther. 2012, 34, 1892-1908 e1891.

169. Jensterle, M.; Kocjan, T.; Kravos, N.A.; Pfeifer, M.; Janez, A. Short-term intervention with liraglutide improved eating behavior in obese women with polycystic ovary syndrome. Endocr. Res. 2015, 40, 133-138.

170. Jensterle Sever, M.; Kocjan, T.; Pfeifer, M.; Kravos, N.A.; Janez, A. Short-term combined treatment with liraglutide and metformin leads to significant weight loss in obese women with polycystic ovary syndrome and previous poor response to metformin. Eur. J. Endocrinol. 2014, 170, 451-459.

171. Feng, P.; Yu, D.M.; Chen, L.M.; Chang, B.C.; Ji, Q.D.; Li, S.Y.; Zhu, M.; Ding, S.H.; Zhang, B.Z.; Wang, S.L.; et al. Liraglutide reduces the body weight and waist circumference in chinese overweight and obese type 2 diabetic patients. Acta Pharmacol. Sin. 2015, 36, 200-208.

172. Shao, Y.; Yuan, G.; Feng, Y.; Zhang, J.; Guo, X. Early liraglutide treatment is better in glucose control, beta-cell function improvement and mass preservation in $\mathrm{db} / \mathrm{db}$ mice. Peptides 2014, 52, $134-142$.

173. Russo, G.T.; Labate, A.M.; Giandalia, A.; Romeo, E.L.; Villari, P.; Alibrandi, A.; Perdichizzi, G.; Cucinotta, D. Twelve-month treatment with liraglutide ameliorates visceral adiposity index and common cardiovascular risk factors in type 2 diabetes outpatients. J. Endocrinol. Investig. 2015, $38,81-89$.

174. Inoue, K.; Maeda, N.; Fujishima, Y.; Fukuda, S.; Nagao, H.; Yamaoka, M.; Hirata, A.; Nishizawa, H.; Funahashi, T.; Shimomura, I. Long-term impact of liraglutide, a glucagon-like peptide-1 (glp-1) analogue, on body weight and glycemic control in japanese type 2 diabetes: An observational study. Diabetol. Metab. Syndr. 2014, 6, 95.

175. Iglesias, P.; Civantos, S.; Vega, B.; Pavon, I.; Guijarro, G.; Monereo, S. Clinical effectiveness of exenatide in diabetic patients waiting for bariatric surgery. Obes. Surg. 2015, 25, 575-578.

176. Flint, A.; Raben, A.; Ersboll, A.K.; Holst, J.J.; Astrup, A. The effect of physiological levels of glucagon-like peptide-1 on appetite, gastric emptying, energy and substrate metabolism in obesity. Int. J. Obes. Relat. Metab. Disord. 2001, 25, 781-792.

177. Bradley, D.P.; Kulstad, R.; Racine, N.; Shenker, Y.; Meredith, M.; Schoeller, D.A. Alterations in energy balance following exenatide administration. Appl. Physiol. Nutr. Metab. 2012, 37, 893-899. 
178. Pannacciulli, N.; Bunt, J.C.; Koska, J.; Bogardus, C.; Krakoff, J. Higher fasting plasma concentrations of glucagon-like peptide 1 are associated with higher resting energy expenditure and fat oxidation rates in humans. Am. J. Clin. Nutr. 2006, 84, 556-560.

179. Flint, A.; Raben, A.; Rehfeld, J.F.; Holst, J.J.; Astrup, A. The effect of glucagon-like peptide-1 on energy expenditure and substrate metabolism in humans. Int. J. Obes. Relat. Metab. Disord. 2000, 24, 288-298.

180. Hughes, T.E.; Kim, D.D.; Marjason, J.; Proietto, J.; Whitehead, J.P.; Vath, J.E. Ascending dose-controlled trial of beloranib, a novel obesity treatment for safety, tolerability, and weight loss in obese women. Obesity (Silver Spring) 2013, 21, 1782-1788.

(C) 2015 by the authors; licensee MDPI, Basel, Switzerland. This article is an open access article distributed under the terms and conditions of the Creative Commons Attribution license (http://creativecommons.org/licenses/by/4.0/). 